В.А. Маслова

\title{
ТЕМА МЕЛАНХОЛИИ ВО ФРАНЦУЗСКОМ СИМВОЛИЗМЕ
}

\begin{abstract}
Аннотация. В статье рассматриваются причины и следствия актуализации темы пессимизма, уныния, отчаяния во французском символизме в конце XIX века, а также анализируются причины развития феномена меланхолии в XX веке на материале художественной практики франиузских символистов, рассматриваемой преимущественно в поэзии, критических статьях символистов, а также аналитических искусствоведческих, исторических, литературно-философских работ, посвященных французскому символизму или касающихся темы меланхолии. Данная тема, а более широко ее можно охарактеризовать и как сплин, печаль, тоска, разочарование, неудовлетворенность, безнадежность, исключительно характерна для творчества поэтов символистов и декадентов. Это обусловлено как общей интеллектуальной атмосферой конца XIX в., так и теми задачами в искусстве, которые ставили перед собой представители течения символизма. Методами исследования послужили описательный, системный, сравнительный и культурно-исторический подход. Французский символизм рассматривается с феноменологической точки зрения.

Постановка проблемы обусловлена не столько поводом для обращения к анализу данной темы в частных примерах лирики французского символизма, хотя данная тема не изучена пока в достаточной степени, а сколько тем, что, как нам представляется, эсхатологические настроения того времени дали проекций в ХХ в. гораздо больше, чем принято считать, причем не только в искусстве, но и в теоретическом осмыслении оного.

Ключевые слова: французский символизм, меланхолия, сплин, тоска, С. Малларме, Ш. Бодлер, интериоризация, пессимизм, фантасмагория, fin de siècle.
\end{abstract}

$\mathrm{T}$

ермин «меланхолия» был введен Гиппократом (по-гречески $\mu \varepsilon \lambda \alpha v \chi о \lambda i ́ \alpha$ буквально обозначает — «черная желчь»). В Древней Греции меланхолия означала уныние, задумчивость, также душевную болезнь, о ней упоминается в произведениях Гомера, Аристотеля, Платона и Цицерона. В творчестве позднего Средневековья и Возрождения тема меланхолии широко обсуждалась и служила популярным сюжетом, например, в изобразительном искусстве. Запрос на меланхолию существовал в обществе и творческом сообществе. Блистательный шедевр - гравюра А. Дюрера «Меланхолия» (1514 г.) и картина «Аллегория меланхолии» (1532 г.) Л. Кранаха Старшего тому убедительные свидетельства.

Новый этап эволюции концептуализации меланхоличности происходит в период утверждения романтизма и в особенности французского символизма. Он не может быть достоверно оценен вне связи с базовыми сущностями символизма, возникшего как рефлексия на посыл индустриального общества, о законах науки как безальтерна- тивных путях постижения мира и о господстве философии позитивизма. Символизм закономерно возник как художественно-эстетическое направление, протестующее против набирающей в тот период успех теории эволюции Дарвина и позиционированию наукой и обществом человека как истинного преобразователя природы. Размышления о смене парадигмы своего времени, неизбежной спутницы прогресса и последующих политических, экономических и социальных переделов, явили символистов в этом смысле как последователей представителей романтизма, но по-новому осмысливающих уже сами принципы искусства, и в отличие от последних полагавших первостепенной для себя задачу проникновения в символическую природу вещей.

Характер этой связи между, например, Э. Золя и С. Малларме, как ничто лучше, отражает роман Ж.-К. Гюисманса «Наоборот». Провозглашается идея поэмы в прозе. Налицо возврат к спиритуализму, отвечающему общему настроению времени, напитанному глубоким пессимизмом. 


\section{Психология и психотехника 5(68) • 2014}

\section{Пессимизм - новая черта интеллектуальной атмосферы эпохи}

Достаточно беглого взгляда на популярнейшее в то время поэтическое произведение П. Верлена «Изнеможение» из цикла «Меланхолия»; как становится очевидным не только в какой степени распространились пессимистические настроения среди интеллектуальной элиты того времени, но и то насколько полиморфен, тонок и глубок сам язык рефлексии на эту тему.

\section{Я чувствую себя Империей на грани Упадка в ожиданьи варварской орды, Когда акростихи, как дряблые плоды Изнеможения, слагаются в дурмане. Душа в разладе с сердцем, о кровавой брани, Уже начавшейся, твердят на все лады. Но я-то что могу? Волненья мне чужды. Но я-то что хочу? Все прожито заранее. Не мочь и не хотеть - ни жить, ни умереть! Все выпито. Батилл, ну что ты зубы скалишь? Все съедено. Молчи! Останется тоска лишь Да этот бедный стих - в огне ему гореть! Да этот подлый раб - поди добейся толку! Да эта скука, что сожрет вас втихомолку ${ }^{1}$.}

Истоки пессимизма весьма разнообразны. Они, по меньшей мере, политические, экономические, научные и философские.

Так, поражение во франко-прусской войне (1870 г.) и катаклизмы времен Парижской коммуны воспринимались французским обществом, как конец цивилизации. Масштабы перемен сравнивали не менее, чем с падением Римской империи или нашествием варваров. События подтолкнули мыслителей того времени, И. Тэня и Э. Ренана к глубокому переосмыслению не только канонов Французской революции, но и философии Ж.-Ж. Руссо, принципов демократии и даже самой идеи республики. Противоречиво, но факт, что в то же время, на выборах 1879 года, во Франции окончательно утверждается республиканская форма правления, а 14 июля вновь становится национальным праздником. В обществе это, по меньшей мере, не способствовало усилению тренда оптимизма.

Неудивительно, что в последней трети XIX века творчество выдающихся представителей гуманистического романтизма Ж. Мишле, В. Гюго и

1 Проклятые поэты / Пер. с фр. М. Яснова. СПб., 2007. С. 21.
А. де Ламартина (которые были сторонниками республиканских идей) уже вызывает неприятие у значительной части интеллектуальной элиты, которая видела в принципе равенства и во всеобщем избирательном праве уже не идеалистическую иллюзию, а угрозу своему существованию. Речь идет о весьма значительном и влиятельном круге интеллектуальной элиты, ориентировавшейся на французскую аристократию. Если учесть наблюдающийся в этот период глубокий кризис дворянства как социального сообщества, пессимистические настроения и естественны, и неизбежны. Весьма характерны для того времени внутренние парадигмы главного героя романа «Наоборот» дез Эссента, прототипом которого был выдающийся мыслитель и эстет герцог де Монтескью. Он же, кстати, послужил прототипом и персонажа романа М. Пруста «В поисках утраченного времени» барона де Шарлюса. Мы же подчеркнем, что носителем этих душевных трансформаций является интеллигенция. В. Лепенис, автор книги «Меланхолия и общество», тонко отмечает, что «... в XX веке носителем меланхолии становится интеллигенция этот “жалующийся класс", девиз которого выразил П. Валери: "Я жалуюсь, следовательно, существую". Кульминацией этой меланхолии становится, по В. Лепенису, 1989 год и падение социалистических режимов в Европе»².

Экономические причины возникновения атмосферы пессимизма в XIX веке налицо. Конец XIX века - это начало развития индустриального общества, идет масштабное распространение машинного производства, применение достижений научно-технического прогресса, активное развитие рынка товаров и услуг. Эти процессы повлекли за собой изменения не только в духовной, но и в материальной жизни. Ш. Бодлер хотел покончить жизнь самоубийством из-за вульгарного по нынешним меркам “засилья" ежедневных газет, которые начали в то время выпускаться большим тиражом: «Газеты делают мою жизнь невыносимой»³. Как он говорил, они вынуждают его убежать в

\footnotetext{
2 Цит. по: Магун А.В. К истокам мрачных чувств. Негативная аффектация между меланхолией и терроризмом // Новое Литературное Обозрение. НЕПРИКОСНОВЕННЫЙ ЗАПАС. 3/2013. № 89. (URL: http://www.nlobooks.ru/node/3729 (дата обращения 16.12.13)).

3 Цит. по: Compagnon A. Baudelaire et les "petits journaux» // Le Huffington Post. 2012. (URL: http://www.huffingtonpost.fr/ antoine-compagnon/facebook-twitter-baudelaire-et-les-petitsjournaux_b_1245100.html (дата обращения 16.12.13)).
} 


\section{Философия и психология}

«мир, где таких газет еще нет» ${ }^{4}$. А. Компаньон сравнивает это явление с нашим временем: «Это тоже самое, если бы молодой юноша или девушка сегодня решил застрелиться из-за существования множества параллельных миров, как Web 2.0, Facebook или Твиттер, современные аналоги ежедневных газет для Бодлера» ${ }^{5}$. Почему данное явление было настолько значимо для поэта? «Газета была символом нового мира, а именно, - духовного упадка. Ее появление означало исчезновение поэзии, подмену прекрасного утилитарным, искусства техникой, культ материи, исчезновение любого вида трансцендентности: «Каждая газета с первой до последней строчки, представляет собой всего лишь ряд жестокостей. Войны, преступления, кражи, распутство, пытки, злодеяния правителей, преступления государств, отдельных людей, упоение всемирной жесткостью» ${ }^{6}$. И тем не менее отметим, что позднее Ш. Бодлер становится основателем одной из парижских газет, он принял перемены.

Тренд «жестокости», преобладавший в газетах XIX в., парадоксальным образом стал главенствующим в СМИ XX-XXI вв. А. Магун видит это явление шире и объединяет его понятием "отрицательная аффектация": «Современная культура пронизана формами отрицательной аффектации: здесь и критическая настроенность СМИ, и присущая им же шоковая сенсационность, катастрофизм новостей, и культивация жесткого насилия в массовом искусстве, и широко распространенная и обсуждаемая в обществе психопатологическая симптоматика депрессии» ${ }^{7}$. Исследователь указывает на разные причины возникновения этого процесса. Это в первую очередь, необходимость в «шоковости», на это указывает еще В. Беньямин в работе «0 некоторых мотивах у Бодлера». В индустриальном обществе все построено на монотонном повторении, механизации, начиная с рабочего процесса на конвейере, кончая осязательным опытом «многоходового механизма резкого движения руки» ${ }^{8}$. Благодаря

\footnotetext{
4 Там же.

5 Там же.

6 Там же.

7 Магун А.В. К истокам мрачных чувств. Негативная аффектация между меланхолией и терроризмом // Новое Литературное Обозрение. НЕПРИКОСНОВЕННЫЙ ЗАПАС. 3/2013. № 89. (URL: http://www.nlobooks.ru/node/3729 (дата обращения 16.12.13)).

8 Беньямин В. О некоторых мотивах у Бодлера (отрывок) / Пред. и пер. с нем. А. Магуна // Синий диван. 2001. № 1. С. 113.
}

этому человек как бы впадает в оцепенение, он «... начинает жить только тем, что он «переживает»в эту конкретную минуту или, максимум, в этот час. Подобное переживание, чтобы отпечататься в памяти, должно компенсировать шоковой силой то, что оно теряет в протяженности и богатстве» ${ }^{9}$. Таким образом, «шоковость» принадлежит онтологии общества. Человек уже не может без нее, она сопровождает индивидуума как на улице, в транспорте, так и в СМИ, в искусстве, - в жизни.

Для понимания контекста конца XIX века обратимся к работе В. Брюсова, где он цитирует созвучную настроениям Ш. Бодлера позицию Ж. Бизе: «Ваш прогресс, - пишет Бизе, - неизбежный, неумолимый, убивает искусство. Бедное мое искусство! Общества, наиболее зараженные суевериями, были великими двигателями в области искусства: Египет, Эллада, эпоха Возрождения [...]. Докажите мне, что у нас будет искусство разума, истины, точности, и я перейду в ваш лагерь!»10. Налицо глубокие сомнения в том, что общество, зараженное атеизмом и верой в научно-технический прогресс, окажется для искусства полезным.

Победоносное шествие науки также внесло свою лепту в формирование общей атмосферы сплина и меланхолии в первую очередь по ушедшим временам. Прогресс гуманитарных и естественных наук (биология, психология, социология) открыл феномен бессознательного. Выяснилось, что человеческое поведение определяется многими факторами и поддается анализу, научному анализу. Это изменило взгляды коренным образом на устоявшееся картезианское мышление и привело к переосмыслению философских основ либерализма, постулирующих примат свободы воли и индивидуального разума. Естественным образом обосновывается позиция о субъективности познания. Звучат высказывания о том, что возможности науки ограничены и есть необходимость в идеальном.

Наука эпохи позитивизма девальвирует демократию. На авансцену выходит фатализм и новая теория социального дарвинизма, согласно которой закономерности естественного отбора и борьбы за существование в природе, распространяются на отношения в человеческом обществе. Э. Золя в 1881 г. в одной из его программных статей в 1880-1881 гг. в Фигаро пишет: «Никакой народ не является толь-

\footnotetext{
9 Там же. С. 109.

10 Цит. по: Брюсов В. Собрание сочинений. В 7-ми тт. Т. VI. M., 1975. C. 160.
} 
ко суммой количества людей, его составляющих [...]. Вот почему все научное сообщество нашего времени и с недоверием, и колебаниями относится к идее всеобщего избирательного права. Я говорю о наших философах, ученых, о тех, кто действует с помощью наблюдения и эксперимента. Они отрицают абсолют, они изучают человека вне догм и они считают, что физиологическое равенство отсутствует, что один человек не стоит другого, что существует постоянный и неизбежный отбор, который касается почти половины человечества. Так что всеобщее избирательное право не является реальностью, основанной на истине, но идеалом, опирающимся на религиозную концепцию равенства душ» ${ }^{11}$. Более того, достижения в биологии, палеонтологии, археологии и филологии поставили под сомнение истинность Священного писания. Догмы католической религии становятся излюбленной мишенью позитивистски настроенных мыслителей того времени. Религиозное мышление воспринимается как анахронизм, а его ослабление между тем подпитывает пессимизм современников, формируется «разочарованное поколение». Ю. Кристева отмечает: «Эпохи, когда наблюдается крушение религиозных и политических идолов, эпохи кризиса особенно склонны к черной желчи» ${ }^{12}$. Настроения того времени хорошо характеризует появившееся в 1880-90 гг. во Франции выражение «Fin de siècle», которое быстро распространилось потом и в других странах. Важно подчеркнуть то, что именование «конец века» знаменует собой не время конца XIX века, а особое умонастроение, характеризуемое утонченностью переживаний, нервной обостренностью ощущений, пессимизмом, усталостью от жизни, чувством приближающегося конца света, пресыщением жизнью, очарованием смертью, беззаботностью, фривольностью и декадансом. Д.С. Мережковский напишет в 1891 году в Париже произведение «Конец века»:

\section{Столица роскоши, на празднике твоем \\ Я вижу иногда рабочего с лицом, \\ Исполненным немой, загадочною думой. \\ Проходит он, как тень, безмолвный и угрюмый, Со взором пристальным завистливых очей... \\ 0 , гость непрошеный на пире богачей, \\ Мне страшно при тебе за этот праздник вечный,}

11 Цит. по: Marchal B. Lire le Symbolisme. Paris, 1993. Р. 36-37.

12 Кристева Ю. Черное солнце: Депрессия и меланхолия. M., 2010. C. 14 .
За легкую толпу, за смех ее беспечный, За яркие кафе и величавый ряд

Твоих, о Новый Рим, блистательных громад! Ты, как богач, сказал: «У нас именья много, Ешь, пей и веселись!» И ты забыл про Бога, Но скорбь великая растет в душе у всех...

Надолго ль этот пир, надолго ль этот смех? Каким путем, куда идешь ты, век железный? Иль большецели нет, и ты висишь над бездной $?^{13}$

Созданию новой интеллектуальной атмосферы способствовало также появление работ некоторых мыслителей, несущих в себе онтологически переосмысленное понимание мира. Примечательны работы Г. Спенсера, которые выводят понимание человека далеко за пределы материалистического мира. Активно вводится понятие непознаваемого, согласно которому бессознательное может быть обителью тьмы или света. И обителью чего именно оно станет в каждом конкретном случае неизвестно. Культивирование этой идеи происходит в работах А. Шопенгауэра, Н. Гартмана, содержание которых оставят печать безнадежного пессимизма в умах целого поколения.

Первые переводы работ А. Шопенгауэра появились во Франции в 1877 году. Его «Афоризмы и максимы» становятся для многих писателей Библией пессимизма. Ж.К. Гюисманс в своей книге «Наоборот»: «Ах, он один познал истину! Чем были все евангельские фармакопеи рядом с его трактатом о духовной гигиене! Он ничего не намеревался излечивать, не предлагал больным никакой награды, никакой надежды, но его теория пессимизма была, в конце концов, великой утешительницей для избранных умов и возвышенных душ. Она показывала общество как оно есть, настаивала на глупости женщин, указывала вам на избитые дороги, спасала вас от разочарований, предостерегая от того, чтобы по возможности сократить ваши упования, не питать их совершенно, если есть у вас на это сила, и, наконец, считать себя счастливым, если неожиданно не свалится вам на голову грязная черепица» ${ }^{14}$.

\footnotetext{
13 Мережковский Д.С. Стихотворения и поэмы / Вступ. ст., сост., подгот. текста и примеч. К.А. Кумпан. Новая Библиотека поэта. СПб.: Академический проект, 2000. 928 c. (URL: http://merezhkovsky.ru/lib/poetry/konets-veka.html (дата обращения 16.12.13)).

14 Гюисманс Ж.К. Собрание сочинений: В 3-х тт. Т. 1. М.,
} 2010. C. 331. 


\section{Философия и психология}

Еще раньше появились во Франции переводы работ Э. Свёденборга и Э.Т.А. Гофмана. Именно они, по-видимому, питали первоначально концепцию Ш. Бодлера, в которой появляется понятие «соответствия единства чувств», как некое воспоминание об утраченной гармонии, глубоко скрытые в человеческой натуре. В этом смысле символизм неразрывно связан с категорией современности. «Если современное состояние предполагает разрушение старого порядка, то именно по этой причине оно является необходимым условием для особого восприятия этой золотой безвозвратно исчезнувшей эпохи, и для меланхолического воплощения в поэтической форме. Ностальгическое мировосприятие, свойственное символизму устанавливает, таким образом, связь между чувственным опытом и пессимистической концепцией истории» 15 .

\section{Цели искусства для французских символистов}

Обращение к теме меланхолии в творчестве французских символистов связано не только с многообразными факторами «атмосферы» того времени. В значительной мере это вытекало из тех же целей в искусстве, которые они перед собой ставили. Задачи, за решение которых взялись французские символисты, сформировались, безусловно, не на пустом месте, а как рефлексия, уходящая своими истоками в недавнее культурологическое прошлое.

Задача поэта символиста - открытие идеи через ее фигуративную репрезентацию. Характерна трансцендентальность этой идеи, так А.А. Потебня в книге «Мысль и язык» (1862 г.) пишет: «Только теперь, при существовании для нас символизма слова (при сознании внутренней формы), его звуки становятся внешнею формою, необходимо требуемою содержанием» ${ }^{16}$. Французский поэт символист ставит перед собой задачу ухватить связи между видимыми, ощущаемыми явлениями мира с их непознаваемой сутью, подняться от следствия к причине, от образа к прототипу, от внешних проявлений к их таинственному смыслу. В тоже время он должен презентовать вещи через их внешние качества, уметь облечь идею в фигуративное значение, высказывать истину через образы и аналогии. Тогда только творческая единица может достигнуть

15 Rapetti R. Le symbolisme. Paris, 2007. P. 144.

16 Потебня А.А. Эстетика и поэтика / Ред. колл.: М.Ф. Овсянников (пред.) и др.; сост. вступит. статья и примеч. И.В. Иваньо и А.И. Колодной. М., 1976. С. 177. полного понимания символов скрытых за вещами видимого мира, у нее больше не будет нужды рассказывать легенды или анализировать страсти, но будет лишь нужно одно: сосредоточится на поиске соответствий между вещами, идеями и снами.

Целью символистов является «...духовная революция, постижение духовных структур Универсума посредством чистой поэзии, проникновение в сущность последней, преобразование реальности на поэтических началах, то есть [...]. Символ для них - метафорическое выражение Универсума, указывающее на духовную реальность; это и принцип сотворения мира, и способ поэтического творчества, свидетельствующий о божественной функции поэта символиста - провидца, приобщенного к высшей реальности» ${ }^{17}$.

Речь идет о возбуждении в читателе такого же состояния «просветления», которое возникает у поэта во время его творческого вдохновения. Точнее даже речь идет о том, чтобы «дать людям напоминание о том, что они никогда не видели». Каким образом? Если подобное состояние нельзя описать, то его можно подсказать, внушить. «Назвать предмет - значит на три четверти разрушить наслаждение от стихотворения - наслаждение, заключающееся в самом процессе постепенного и неспешного угадывания; подсказать с помощью намека - вот цель, вот идеал» ${ }^{18}$.

Верлен желал, чтобы поэт обладал языком, который мог бы приспосабливаться к разнородным состояниям своей души, который смог бы соответствовать интуиции этой неясной связи. Очевидно, что невозможно достичь идеальной прецизионности между языком и мыслью. Между словом, по сути, статичным и постоянными трансформациями душевного, есть только связь приблизительная и сложно определяемая. Символ увязан с индивидуальной концепцией реальности, сведенной к внутренней эмоциональной жизни и относительности меняющегося будущего. Если бы метафора была чисто субъективной, то поэт не мог бы донести до читателя нюансы своего душевного состояния. Следовательно, существуют некие объективные связи между меняющимися состояниями души, вещами и

\footnotetext{
17 Маньковская Н.Б. Эстетическое кредо французского символизма // Эстетика: Вчера. Сегодня. Всегда. Вып. 5. М., 2012. C. 22.

18 Малларме С. О литературной эволюции (интервью) (1891) // Поэзия французского символизма. Лотреамон. Песни Мальдорора / Под ред. Г.К. Косикова. М., 1993. С. 425.
} 
поэтическим языком. Задача поэта - поиск такого языка. Этот язык не совпадает с языком обыденным, потому что такой язык описывает лишь обыденные связи между вещами и явлениями.

Символизм обозначает попытку преодолеть индивидуальное поэтическое и достичь более высокой степени обобщения. Символизм провозгласил это целью любой подлинной поэзии. Каковы же пути, на которых символисты пытались воплотить в жизнь поставленные ими задачи в искусстве, если речь идет о творчестве, которое отрицает установленный ранее один из главных принципов искусства - мимесис? Какой из них привел символистов к теме меланхолии?

Символизм пример того, какие превратности подстерегают тех, кто встал на путь самоуглубления через прорыв в бессознательное. «Мировоззренческая потребность изначально присуща человеку. Она сохраняет свою силу и при распаде сознания. Однако «схождение с ума» становится притягательным, и люди начинают играть с рассудком, не боясь его потревожить» ${ }^{19}$. Погружение в бездны человеческой души в поисках высшей реальности неизбежно проходит в некоторой точке перегиба, после которой пути конкретных творческих единиц могут быть разными. Культивируя ощущения, доставляемые зрением, слухом или обонянием, человек ограничивает себя субъективного в рамках своего опыта и потому он порой обретает не видение истиной картины мироздания, а лишь мозаику собственной субъективности. В силу этого, символисты приходят к грусти, тоске, меланхолии. Невозможность реализовать себя ведет к разочарованию в искусстве, и в жизни. Великий А. Рембо в конце своей жизни уходит из профессии и перестает писать.

Для достижения прорыва в мир идей, подчас используются в качестве помощника психотропные средства, алкоголь и т.д. Шаманы, пифии (например, в храме Аполлона в Дельфах) прибегали к наркотическим средствам для достижения медитативных, экстатических состояний, но в ту эпоху техники использования данных средств передавалось из поколения в поколение, и были доведены до совершенства, что минимизировало побочные эффекты. Для символистов это чаще было фатально. В XVIII веке использование опиума, а в XIX веке и кокаина для медицинских целей считалось обыденным. Феномен наркозависимости не принимался во внимание, но неизбежно и тогда со временем он приводил

19 Гуревич П.С. Психоанализ личности. М., 2011. С. 55. к состоянию сплина, безнадежности. Ш. Бодлер и А. Рембо не были в этом плане исключением.

Более глубокому пониманию взаимосвязи процесса самоуглубления поэта и меланхолии дает анализ понятия интериоризации: «...мышление заключается в интериоризации, помещает вещи вовнутрь и, можно было бы добавить, подвешивает их как возможность: ведь «внутреннее» означает здесь (и вообще в философии) не физическую внутренность человека или земли, не «субъективность» души, но скрытую потенциальность, запертую в интенсивной бесконечности» ${ }^{20}$. По справедливому мнению А. Магуна, художественное творчество и меланхолия невозможны без интериоризации, что свидетельствует об их взаимосвязи. Об этом писал еще Аристотель. «Задолго до Фрейда, с самого начала своего существования как культурного феномена, меланхолия несет отпечаток внутреннего и замкнутого в душе и теле аффекта. Специфика «черной желчи», как отмечает Жан Старобинский, в ее сугубо внутреннем пребывании, которое мешает ее «изгнать» физиологическим или психологическим способом» ${ }^{21}$.

Суммируя вышеизложенное, - творчество поэтов символистов было направлено как бы в «стерильную трансцендентность» ${ }^{22}$. Ю. Кристева отмечает: «Депрессивный человек оказывается сумрачным радикальным атеистом» ${ }^{23}$. С осторожностью, но как мы полагаем можно говорить о символизме как течении, выражающем в художественной форме страх перед современностью, возводящем искусство, «эстетизм» в культ. Символисты чувствовали, что классическое искусство не развивается, а в художественном творчестве начинают действовать другие законы. Это позволяет говорить не только о страхе перед действительностью - современностью, но и перед будущим. Тема болезненности, отчаяния, угнетённости в творчестве поэтов и художников является эквивалентом такого страха.

20 Магун А.В. К истокам мрачных чувств. Негативная аффектация между меланхолией и терроризмом // Новое Литературное Обозрение. НЕПРИКОСНОВЕННЫЙ ЗАПАС. 3/2013. № 89. (URL: http://www.nlobooks.ru/node/3729 (дата обращения 16.12.13)).

21 Там же.

22 См.: Гуго Ф. Структура современной лирики. От Бодлера до середины двадцатого столетия / Пер. с нем. и коммент. Е.В. Головина. М., 2010.

23 Кристева Ю. Черное солнце: Депрессия и меланхолия. M., 2010. C. 11. 


\section{Философия и психология}

Здесь, как нам представляется, тема символизма уже ближе всего соприкасается с позицией фрейдизма. Символ может трактоваться как желание, которое нельзя выразить, а символизация - возвращение вытесненного, - одного из главных механизмов психологической защиты. Синонимами вытеснения являются подавление, репрессия. Именно вытеснение заключается в активном, мотивированном устранении чего-либо из сознания, а по нашему предположению, именно устранении страха.

Символисты стремятся преодолеть индивидуальное и выйти на уровень универсального. Их обращение к сказочным декорам, к древним легендам, к фольклорным традициям, имеет целью достичь больших глубин и «проявить» скрытую реальность. Характерно, что они обращаются более не к индивидуальному бессознательному, а к бессознательному коллективному, к памяти народов, выраженных в легендах. Здесь символисты находят подлинный смысл бытия. Осознав потерю подлинности искусства, они пытаются оказать сопротивление данному феномену, и поэтому, предпринимают попытки его воссоздания, что в живописи уже сделали прерафаэлиты.

3. Фрейд пишет собственно и о меланхолии: «Меланхолия в психическом отношении отличается глубокой страдальческой удрученностью, исчезновением интереса к внешнему миру, потерей способности любить, задержкой всякой деятельности и понижением самочувствия, выражающимся в упреках и оскорблениях по собственному адресу и нарастающим до бреда ожидания наказания» ${ }^{24}$. Причина в возникновении меланхолии для него состоит в объективной утрате чего-либо или кого-либо, это сопровождается тем, что сознание человека не может справиться с чувством потери. Здесь самое главное, что 3. Фрейд связывает переживаемое индивидуально чувство меланхолии с посылами, даваемыми из общества через «опыт экономического подхода», т.е. «...отношениями социального неравенства, фактору бедности, нестабильности материального достатка и т.д. Таким образом, меланхолия всегда связана с неудовлетворением, что делает ее воплощенным конфликтом человека с окружающим миром. Если меланхолия означает раз-

24 Фрейд 3. Печаль и меланхолия // Психология эмоций. Тексты / Под ред. В.К. Вилюнаса, Ю.Б. Гиппенрейтер. М., 1984. (URL: http://psyberlink.flogiston.ru/internet/bits/freud1. htm (дата обращения 16.12.13)). рыв между утраченным прошлым и неизвестным будущим, то оказывается возможным перенесение категории меланхолии из сферы индивидуальной психики в общественно-исторический контекст» ${ }^{25}$. Таким образом, следует вывод о том, что тема меланхолии в произведениях французских символистов с одной стороны была связана с рефлексией общества, в котором налицо были пессимистические настроения, в их творчестве, а с другой стороны, запросом от самого зрителя, читателя, слушателя того времени.

Современная психиатрия полагает, что меланхолия является частным случаем депрессии, а депрессия стала, по мнению Ю. Кристевой, болезнью XX века, о чем косвенно свидетельствует лидерство продаж антидепрессантов. Ю. Кристева справедливо отмечает: «Поскольку время, в котором мы живем, является временем нашего дискурса, чуждая, заторможенная или рассеянная речь меланхолика заставляет его жить в децентрированной темпоральности» ${ }^{26}$. Далее она добавляет: «Напомним, что идея рассматривать депрессию в ее зависимости именно от времени (а не от места) восходит к Канту. Размышляя о ностальгии как особой разновидности депрессии, Кант приходит к заключению, что ностальгирующий желает не место своей юности, но саму свою юность, что его желание стремится вернуть время, а не вещь. Фрейдовское понятие психического объекта, на котором фиксируется больной депрессией, включено в ту же концепцию: психический объект является фактом памяти, он относится к потерянному времени «в прустовском стиле»» ${ }^{27}$.

Нам представляется, что тему отчаяния, грусти, сплина во французском символизме можно связать с концепцией безумия М. Фуко, которую он излагает в работе «История безумия в классическую эпоху». Безумие, по М. Фуко, «образует обнаженную истину человека» ${ }^{28}$. Фуко показыва-

25 Будрайтскис И., Галкина А. Революционная меланхолия // Художественный журнал. 2010. № 75-76. (URL: http://xz.gif. $\mathrm{ru} /$ numbers/75-76/revol-mel/ (дата обращения 16.12.13)).

26 Кристева Ю. Черное солнце: Депрессия и меланхолия. M., 2010. C. 72.

27 Там же. С. 73.

28 Фуко М. Безумие, отсутствие творения // Фигуры Танатоса: Искусство умирания. Сб. статей / Под ред. А.В. Демичева, М.С. Уварова. СПб., 1998. С. 203-211. (URL: http:// anthropology.ru/ru/texts/foucault/thanatos04_22.html (дата обращения 16.12.13)). 
ет, что «...начиная с XIX в. современная культура непреднамеренно, неосознанно создавала такой образ психической болезни, в который можно вглядываться, ища разгадки собственной сущности, ибо психическая болезнь понимается как проявление этой скрытой сущности» ${ }^{29}$. М. Фуко говорит о том, что через безумие открывается истина мира и именно посредством слова, речи. Существует связь безумия с возникшей новой литературой конца XIX века, основанной на едином поле рождения и выражения. До С. Малларме в литературе существовал некий единый язык, в рамках которого писатель имел право устанавливать свою речь. Вследствие этого «...литературное произведение имело природу, общую со всяким другим языком, почти те же самые знаки (безусловно, они были величественными), что и Риторика, Сюжет, Образы» ${ }^{30}$. Однако, в конце XIX века, начиная с произведений французских символистов, «... литературное произведение стало речью, записывающей в себе принцип своего расшифрования; или, во всяком случае, оно предполагало - в каждой своей фразе, в каждом из своих слов - способность суверенно менять ценности и значения языка, к которому оно все же принадлежит (по справедливости); оно приостанавливало власть языка в самом жесте современного письма» ${ }^{31}$. Наиглавнейшем является то, что «Открывшееся как язык, который замалчивает себя, поскольку сам на себя накладывается, безумие не может ни обнаружить, ни дать слова какому-то творению (ни чему-то такому, что при участии гения или удачи могло бы стать творением); оно обозначает пустоту, из которой исходит это творение, то есть место, в котором оно непрестанно отсутствует, в котором его никогда нельзя найти, поскольку оно там никогда не находилось» ${ }^{32}$. Полагаем, что чрезмерно заострять внимание на связи безумия и литературы не следует, это только одна из точек видения, с которой можно рассматривать символизм сегодня.

29 Фуко М. История безумия в классическую эпоху. СПб., 1997. C. 13.

30 Фуко М. Безумие, отсутствие творения // Фигуры Танатоса: Искусство умирания. Сб. статей / Под ред. А.В. Демичева, М.С. Уварова. СПб., 1998. С. 203-211. (URL: http:// anthropology.ru/ru/texts/foucault/thanatos04_22.html (дата о6ращения 16.12.13)).

31 Там же.

32 Там же.
В заключении следует отметить, что, как правило, французский символизм рассматривается с позиций различных дисциплин: искусствоведческой, эстетической, филологической, культурологической. Мы попытались это сделать с феноменологической точки зрения, рассмотрев это направление в искусстве в аспекте меланхолии и с позиций темпоральности в рамках анализа причинно-следственных отношений становления и развития его на протяжении XIX - XX веков.

Признание определенного течения в искусстве или художника в обществе зависит от степени готовности воспринять определенное творчество публикой. «Рассмотрение произведений символистов это всегда творчество и сотворчество. И не всем оно было доступно даже тогда, когда символизм развивался. Мало того, что в основе своей такое восприятие искусства было глубоко идеалистично, необходим был некий “настрой”, некая “эстетическая эмоция” (выражение Г. Чулкова). Есть она - и произведение “открыто”, завлекая в смысловые дали. Вне такого подхода символистское произведение становится непонятным, а порой и нелепым» ${ }^{33}$. Стоит отметить, между тем, что попытка выражения невыразимого - бессознательного на эмпирическом уровне предпринималась и до и после символистов. Французский символизм оказал большое влияние на русский символизм, позднее на такие несхожие между собой течения, как фовизм, экспрессионизм, сюрреализм.

Анализ связи меланхолии и художественного творчества приводит к выводу, что с одной стороны, общественный, философский, и художественный контекст воздействует на художника, а с другой стороны, идеи символизма, воспроизведенные в манифестах, воздействуют на общество. В прозе и критике Ш. Бодлер, С. Малларме, А. Рембо, П. Верлен и другие представители обсуждаемого направления ставя перед собой личностно разные цели, но, находясь на одном пути, пришли сначала к осознанию, а затем и созданию начал современной лирики, новому отношению к слову и тексту.

33 Турчин В. Призрачное... неполное бытие. Об одной важной формально-смысловой компоненте в структуре символистского образа // Дух символизма. Русское и западноевропейское искусство в контексте эпохи конца XIX - начала XX века. М., 2012. С. 88. 


\section{Философия и психология}

\section{Список литературы:}

1. Беньямин В. О некоторых мотивах у Бодлера (отрывок) / Пред. и пер. с нем. А. Магуна // Синий диван. 2001. № 1. C. 107-122.

2. Брюсов В. Собрание сочинений. В 7-ми тт. T. VI. М., 1975.

3. Будрайтскис И., Галкина А. Революционная меланхолия // Художественный журнал. 2010. № 75-76. (URL: http://xz.gif.ru/numbers/75-76/revol-mel/ (дата обращения 16.12.13)).

4. Гуго Ф. Структура современной лирики. От Бодлера до середины двадцатого столетия / Пер. с нем. и коммент. Е.В. Головина. М., 2010.

5. Гуревич П.С. Психоанализ личности. М., 2011.

6. Гюисманс Ж.К. Собрание сочинений: В 3-х тт. Т. 1. М., 2010.

7. Кристева Ю. Черное солнце: Депрессия и меланхолия. М., 2010.

8. Магун А.В. К истокам мрачных чувств. Негативная аффектация между меланхолией и терроризмом // Новое Литературное Обозрение. НЕПРИКОСНОВЕННЫЙ ЗАПАС. 3/2013. № 89. (URL: http://www. nlobooks.ru/node/3729 (дата обращения 16.12.13)).

9. Малларме С. О литературной эволюции (интервью) (1891) // Поэзия французского символизма. Лотреамон. Песни Мальдорора / Под ред. Г.К. Косикова. М., 1993.

10. Маньковская Н.Б. Эстетическое кредо французского символизма // Эстетика: Вчера. Сегодня. Всегда. Вып. 5. М., 2012. С. 20-39.

11. Мережковский Д.С. Стихотворения и поэмы / Вступительная статья, составление, подготовка текста и примечания К.А. Кумпан. Новая Библиотека поэта. СПб.: Академический проект, 2000. (URL: http:// merezhkovsky.ru/lib/poetry/konets-veka.html (дата обращения 16.12.13)).

12. Потебня А.А. Эстетика и поэтика / Ред. коллегия: М.Ф. Овсянников (пред.) и др.; сост. вступит. статья и примеч. И.В. Иваньо и А.И. Колодной. М., 1976.

13. Проклятые поэты / Пер. с фр. М. Яснова. СПб., 2007.

14. Турчин В. Призрачное... неполное бытие. Об одной важной формально-смысловой компоненте в структуре символистского образа // Дух символизма. Русское и западноевропейское искусство в контексте эпохи конца XIX — начала XX века. М., 2012.

15. Фрейд 3. Печаль и меланхолия // Психология эмоций. Тексты / Под ред. В.К. Вилюнаса, Ю.Б. Гиппенрейтер. M., 1984. (URL: http://psyberlink.flogiston.ru/internet/bits/freud1.htm (дата обращения 16.12.13)).

16. Фуко М. Безумие, отсутствие творения // Фигуры Танатоса: Искусство умирания. Сб. статей / Под ред. А.В. Демичева, М.С. Уварова. СПб., 1998. С. 203-211. (URL: http://anthropology.ru/ru/texts/foucault/ thanatos04_22.html (дата обращения 16.12.13)).

17. Фуко М. История безумия в классическую эпоху. СПб., 1997.

18. Хренов Н.А. Символизм в истории становления альтернативной культуры // Культура и искусство. 2012. № 5. C. 82-95.

19. Compagnon A. Baudelaire et les «petits journaux»// Le Huffington Post. 2012. (URL: http://www. huffingtonpost.fr/antoine-compagnon/facebook-twitter-baudelaire-et-les-petits-journaux_b_1245100.html (дата обращения 16.12.13)).

20. Marchal B. Lire le Symbolisme. Paris, 1993.

21. Michaud G. Message poétique du symbolisme. T. I. Paris, 1951.

22. Rapetti R. Le symbolisme. Paris, 2007.

\section{References (transliteration):}

1. Ben'yamin V. O nekotorykh motivakh u Bodlera (otryvok) / Pred. i per. s nem. A. Maguna // Sinii divan. 2001. № 1. S. 107-122.

2. Bryusov V. Sobranie sochinenii. V 7-mi tt. T. VI. M., 1975.

3. Budraitskis I., Galkina A. Revolyutsionnaya melankholiya // Khudozhestvennyi zhurnal. 2010. № 75-76. (URL: http://xz.gif.ru/numbers/75-76/revol-mel/ (data obrashcheniya 16.12.13)). 


\section{Психология и психотехника 5(68) • 2014}

4. Gugo F. Struktura sovremennoi liriki. Ot Bodlera do serediny dvadtsatogo stoletiya / Per. s nem. i komment. E.V. Golovina. M., 2010.

5. Gurevich P.S. Psikhoanaliz lichnosti. M., 2011.

6. Gyuismans Zh.K. Sobranie sochinenii: V 3-kh tt. T. 1. M., 2010.

7. Kristeva Yu. Chernoe solntse: Depressiya i melankholiya. M., 2010.

8. Magun A.V. K istokam mrachnykh chuvstv. Negativnaya affektatsiya mezhdu melankholiei i terrorizmom // Novoe Literaturnoe Obozrenie. NEPRIKOSNOVENNYI ZAPAS. 3/2013. № 89. (URL: http://www.nlobooks.ru/ node/3729 (data obrashcheniya 16.12.13)).

9. Mallarme S. O literaturnoi evolyutsii (interv'yu) (1891) // Poeziya frantsuzskogo simvolizma. Lotreamon. Pesni Mal'dorora / Pod red. G.K. Kosikova. M., 1993.

10. Man'kovskaya N.B. Esteticheskoe kredo frantsuzskogo simvolizma // Estetika: Vchera. Segodnya. Vsegda. Vyp. 5. M., 2012. S. 20-39.

11. Merezhkovskii D.S. Stikhotvoreniya i poemy / Vstupitel'naya stat'ya, sostavlenie, podgotovka teksta i primechaniya K.A. Kumpan. Novaya Biblioteka poeta. SPb.: Akademicheskii proekt, 2000. (URL: http:// merezhkovsky.ru/lib/poetry/konets-veka.html (data obrashcheniya 16.12.13)).

12. Potebnya A.A. Estetika i poetika / Red. kollegiya: M.F. Ovsyannikov (pred.) i dr.; sost. vstupit. stat'ya i primech. I.V. Ivan'o i A.I. Kolodnoi. M., 1976.

13. Proklyatye poety / Per. s fr. M. Yasnova. SPb., 2007.

14. Turchin V. Prizrachnoe... nepolnoe bytie. Ob odnoi vazhnoi formal'no-smyslovoi komponente v strukture simvolistskogo obraza // Dukh simvolizma. Russkoe i zapadnoevropeiskoe iskusstvo v kontekste epokhi kontsa XIX — nachala XX veka. M., 2012.

15. Freid Z. Pechal' i melankholiya // Psikhologiya emotsii. Teksty / Pod red. V.K. Vilyunasa, Yu.B. Gippenreiter. M., 1984. (URL: http://psyberlink.flogiston.ru/internet/bits/freud1.htm (data obrashcheniya 16.12.13)).

16. Fuko M. Bezumie, otsutstvie tvoreniya // Figury Tanatosa: Iskusstvo umiraniya. Sb. statei / Pod red. A.V. Demicheva, M.S. Uvarova. SPb., 1998. S. 203-211. (URL: http://anthropology.ru/ru/texts/foucault/ thanatos04_22.html (data obrashcheniya 16.12.13)).

17. Fuko M. Istoriya bezumiya v klassicheskuyu epokhu. SPb., 1997.

18. Khrenov N.A. Simvolizm v istorii stanovleniya al'ternativnoi kul'tury // Kul'tura i iskusstvo. 2012. № 5. C. 82-95.

19. Compagnon A. Baudelaire et les «petits journaux» // Le Huffington Post. 2012. (URL: http://www. huffingtonpost.fr/antoine-compagnon/facebook-twitter-baudelaire-et-les-petits-journaux_b_1245100.html (дата обращения 16.12.13)).

20. Marchal B. Lire le Symbolisme. Paris, 1993.

21. Michaud G. Message poétique du symbolisme. T. I. Paris, 1951.

22. Rapetti R. Le symbolisme. Paris, 2007. 